DI BENEDETTO, A; GALMARINI, C; TOGNETTI, J. 2018.New insight into how thigmomorphogenesis affects Epipremnum aureum plant development. Horticultura Brasileira 36:330-340 DOI - http://dx.doi.org/10.1590/S0102-053620180308

\title{
New insight into how thigmomorphogenesis affects Epipremnum aureum plant development
}

\author{
Adalberto Di Benedetto ${ }^{1 ; 2}$; Claudio Galmarini ${ }^{3 ; 4}$; Jorge Tognetti ${ }^{2 ; 5}$ \\ ${ }^{1}$ Universidad de Buenos Aires, Ciudad Autónoma de Buenos Aires, Argentina; ${ }^{2}$ Universidad Nacional de Mar del Plata, Balcarce, Provincia \\ de Buenos Aires, Argentina; dibenede@agro.uba.ar (correspondence author); ${ }^{3}$ Universidad Nacional de Cuyo and CONICET; Chacras de \\ Coria, Provincia de Mendoza, Argentina; ${ }^{4}$ Instituto Nacional de Tecnología Agropecuaria EEA La Consulta, La Consulta, Provincia de \\ Mendoza, Argentina; galmarini.claudio@inta.gob.ar; ${ }^{5}$ Comisión de Investigaciones Científicas de la Provincia de Buenos Aires, La Plata, \\ Provincia Buenos Aires, Argentina; jtognetti2001@yahoo.com.ar
}

\begin{abstract}
Climbing Epipremnum aureum plants develop larger leaves than unsupported, hanging plants. This effect may be regarded, in part, as a thigmomorphogenic response, but gravimorphogenetic effect may also be involved, since polar auxin transport is known to be negatively affected in plants with horizontal or hanging stems, which may result in an altered hormone balance at the whole plant level. The present work was aimed at studying how exogenous auxins and cytokinins may influence growth of E. aureum rooted cuttings under different training systems. Rooted cuttings of $E$. aureum were cultivated either climbing on an upright wooden board or creeping on the glasshouse bench or hanging from a basket. All leaves of each plant were sprayed to run-off at sunset with four indole-3-acetic acid (IAA) doses 7 days after transplanting and one week later, with four benzylaminopurine (BAP) concentrations, rendering 16 hormone combination treatments. The application of IAA or BAP at $50 \mathrm{mg}$ $\mathrm{L}^{-1}$ to creeping and hanging plants significantly promoted growth but, in climbing plants, a negative effect was generally observed. Changes in net assimilation and photosynthetic rates, together with modified allometric coefficients, accounted for these responses. The higher growth promotion by exogenous growth regulators observed in creeping or hanging plants compared to climbing plants, may be interpreted mostly as a gravimorphogenetic response.
\end{abstract}

Keywords: auxin, citokinin, foliage plants, gravitropism, leaf growth, leaf anatomy, photosynthesis.

\section{RESUMO}

Nova compreensão sobre como a thigmomorfogênese afeta o desenvolvimento de plantas de Epipremnum aureum

Plantas trepadeiras (Epipremnum aureum) conduzidas suspensas, desenvolvem folhas maiores em comparação com plantas conduzidas sem suporte (rasteiras). Esse efeito pode ser visto, em parte, como uma resposta thigmomorfogênica; mas o efeito gravimorfogênico também pode estar envolvido, uma vez que o transporte polar de auxinas é afetado negativamente em plantas com hastes horizontais ou pendentes, o que pode resultar em um balanço hormonal alterado, a nível da planta como um todo. O presente trabalho teve como objetivo estudar como as auxinas e citocininas exógenas podem influenciar o crescimento de estacas enraizadas de E. aureum sob diferentes sistemas de condução. Estacas enraizadas de E. aureum foram cultivadas como trepadeiras em uma tábua de madeira vertical ou rasteiras sobre bancada em casa de vegetação ou suspensas em uma cesta. Todas as folhas de cada planta foram pulverizadas até escoamento à tarde, com quatro doses de ácido indol-3-acético (AIA), 7 dias após o transplante e, após uma semana, com quatro concentrações de benzilaminopurina (BAP), resultando em 16 tratamentos combinados com hormônios. A aplicação de IAA ou BAP a $50 \mathrm{mg} \mathrm{L}^{-1}$ em plantas rasteiras e suspensas, promoveu crescimento significativo mas, em plantas trepadeiras, observou-se, em geral, efeito negativo. Mudanças na assimilação líquida e taxas fotossintéticas, juntamente com coeficientes alométricos modificados, foram responsáveis por essas respostas. A maior promoção do crescimento por reguladores de crescimento exógenos, observada em plantas rasteiras ou suspensas em comparação com plantas trepadeiras, pode ser interpretada principalmente como uma resposta gravimorfogênica.

Palavras-chave: auxina, citoquinina, plantas de folhagem, gravitropismo,

Received on March 23, 2017; accepted on June 4, 2018

$\mathrm{T}$ he Golden Pothos (Epipremnum aureum), a naturally variegated plant, is a tree-climbing vine native to the Solomon Islands. Golden Pothos varieties are among the most popular tropical ornamental hanging basket crops for interior landscape. In natural tropical settings, 'pothos' can grow to be large plants, producing leaves up to $90 \mathrm{~cm}$ in length. However, plants used for interior landscape purposes usually have heart-shaped leaves that rarely exceed $15 \mathrm{~cm}$ in length. Leaf size depends, among other factors, on how vines are trained. When plants grown in pots under commercial facilities are vertically supported, leaf size significantly increases in comparison to leaves from basket hanging plants (Di Benedetto et al., 2010).

Native shade plants environments 
are characterized by a low light intensity, and for this reason, carbon gain is an important aspect of plant performance. A strategy for maximizing light capture in several shade-adapted plants consists of exploring the vertical environment through the anchorage to an adjacent surface such as host plants, rocks or walls. These changes in plant growth habit modify, in turn, both shoot and root growth (Di Benedetto et al., 2010).

Steinitz et al. (1992) showed that young E. aureum plants with soft stems grow in a vertical downwards hanging manner unless they encounter a surface on which they can climb and grow in a direction that is different from the one given by the gravitational vector. The climbing vine finds anchorage with adventitious aerial clasping roots appraised to an adjacent surface of host plants, rocks or walls.

Steinitz \& Hagiladi (1987) and Steinitz et al. (1992) found that climbing $E$. aureum plants had not only larger leaves, but also shorter internodes and a better-developed aerial root system than unsupported plants that were kept stretched in an upright position by hanging them on a hook at the petiole of the youngest leaf. They suggested that the morphological differences between climbing and free hanging plants represent thigmomorphogenic responses of climbing plants to a mechanical stimulus generated by the contact of the stem with the support surface.

It is well known that many species, including other ornamental shade plants such as Monstera obliqua and Philodendron scandens, have developed sensory mechanisms to detect mechanical stimulation (Steinitz \& Hagiladi, 1987). This stimulation often results in a suite of responses of anatomical, physiological, biochemical, biophysical and molecular nature, termed "thigmo-morphogenesis" (Li \& Gong, 2011), a syndrome that is mediated by auxin, other hormones and signalling molecules as well (Chehab et al., 2009).

However, when comparing climbing plant with plants hanging freely from a pot, an alternative or complementary explanation of the morphologic responses of Golden
Pothos to vine orientation may be given. It is known that stem orientation with respect to the gravity vector determines changes in plant morphology and physiology, a kind of response that has been named 'gravimorphism'. Gravimorphic responses are associated with modified auxin flux, which is known to be inhibited by placing stems in horizontal or downward, instead of upward position. Auxins normally move in a polar manner from shoot to root apices, but in downward-pointing shoots, auxins accumulate near the shoot tip (Lovisolo et al., 2002).

Auxins play key roles in organ development. Organ initiation at the shoot apical meristem is thought to result from localized accumulation of auxin at the site of future primordium development (Monshausen \& Haswell, 2013). Auxins are known to promote the differentiation of lateral roots as well (Pacurar et al., 2014). The latter is a very important control point of plant growth, since root apices are the main source of cytokinins. In turn, cytokinins, which are transported via xylem to the shoot apex, exert a multiple-faced growth promoting action in the aerial part of the plant. Thus, inhibition of polar auxin transport in horizontally or downwardly oriented stems may ultimately result in a decreased whole-plant growth (Keller, 2015). Gravimorphism and thigmomorphism may influence growth at the same time; for example, Steinitz et al. (1992) reported an interaction between $E$. aureum vine orientation and touch response, being only upwards growing vines those sensitive to touch stimuli.

Previous reports have shown that leaf size, leaf number (Di Benedetto et al., 2013, 2015a) and leaf shape (Di Benedetto et al., 2010; De Lojo \& Di Benedetto, 2014) were significantly modified when E. aureum or Monstera deliciosa creeping plants were sprayed with a single 5,50 or $100 \mathrm{mg} \mathrm{L}^{-1}$ 6-benzylaminopurine (BAP) dose. Leaf area and whole-plant biomass accumulation increased with relatively low BAP application (5-50 $\left.\mathrm{mg} \mathrm{L}^{-1}\right)$, while $100 \mathrm{mg} \mathrm{L}^{-1}$ BAP generally appeared as a supra optimal concentration. In these works, BAP-driven growth promotion was associated with increased net assimilation rate (NAR) and net photosynthetic rate.

Exogenous sprays of indole acetic acid on E. aureum plants resulted in morpho-physiological responses that, largely resembled those obtained by BAP sprays, suggesting that growth promotion by exogenous application of both growth regulators may occur via the same signalling cascade (Di Benedetto et al., 2015b).

Examining E. aureum growth patterns under different training systems and in response to exogenously supplied growth regulators may help to understand the contribution of mechanical stimuli and gravity to plant development. Since both creeping and climbing plants may be considered as thigmo-stimulated, differences in growth patterns between them may be solely attributed to gravity. If departure from upward position results in decreased growth due to an impaired auxin transport to the root system, then exogenous auxin and cytokinin application to the foliage should be a straightforward manner to overcome such restriction. The aim of this work was to study E. aureum growth under three different training systems (creeping, climbing or hanging downwards) and to evaluate how exogenously supplied auxin and cytokinin may modify it and, in this context, to gain insight on the hormonal regulation of thigmo-/ gravimorphogenetic responses of $E$. aureum to vine orientation.

\section{MATERIAL AND METHODS}

Rooted cuttings of E. aureum were obtained from a commercial propagator (Vivero Kogiso, Buenos Aires, Argentina), and transplanted into rigid $1,200 \mathrm{~cm}^{3}$ plastic pots (one plant per pot). At the transplant stage, cuttings had on average $3.3 \pm 0.15$ leaves, with $145.49 \pm 24.45 \mathrm{~cm}^{2}$ leaf area and $7.57 \pm 0.83 \mathrm{~g}$ fresh weight per cutting. Pots were filled with a 40-40-20 (v/v/v) mix of Sphagnum maguellanicum peat: river waste: perlite. Plants were watered daily to saturation with high quality tap water $(\mathrm{pH}=6.64$; electrical conductivity $\left.=0.486 \mathrm{dS} \mathrm{m}^{-1}\right)$ and were fertilized each 
week with $50 \mathrm{mg} \mathrm{L}^{-1} \mathrm{~N}$ as 1.0: 0.5: 1.0: $0.5(\mathrm{v} / \mathrm{v} / \mathrm{v} / \mathrm{v}) \mathrm{N}:$ P: K: Ca (nitric acid, phosphorus acid, potassium nitrate and calcium nitrate) via overhead irrigation water.

The experiment was carried out in a greenhouse at the Faculty of Agronomy, University of Buenos Aires, Argentina ( $34^{\circ} 28^{\prime}$ 'S), from September $8^{\text {th }}, 2007$ to March $12^{\text {th }}, 2008$. Plants were cultivated either climbing (supported through an upright wooden board $5 \mathrm{~cm}$ in width and $100 \mathrm{~cm}$ in length, coated with black polyethylene), creeping on the glasshouse bench or hanging from a basket, to obtain three different growth habits. Both climbing and creeping plants were assumed thigmo-stimulated, being their aerial roots in contact with the respective surfaces (either wooden board or bench surface). Care was taken to ensure similar light exposure to the plants regarding the training system employed. The greenhouse was covered with a black shade light cloth for $50 \%$ full sun, divided into three blocks, and within each block, 160 plants were grown under each training system. The red:far-red ratio (R:FR) was not significantly modified by the shade-cloth, as shown by a $660 / 730$ sensor (Skye Instruments, Wales, UK). Daily mean temperatures ranged between 21.80 to $37.50^{\circ} \mathrm{C}$ and daily photosynthetic active radiation between 14.80 to 25.64 molphotons $\mathrm{m}^{-2}$ day $^{-1}$ during the experiment. Temperature and light intensity were recorded with three HOBO sensors (H08-004-02) (Onset Computer Corporation, MA, USA) connected to a HOBO H8 data logger.

Seven days after transplantation, all leaves of each plant were sprayed to runoff at sunset with IAA solutions $(0,5$, 50 , or $100 \mathrm{mg} \mathrm{L}^{-1}$ ), followed 7 days later by sprays with BAP solutions $(0,5,50$, or $100 \mathrm{mg} \mathrm{L}^{-1}$ ), rendering 16 hormone combination treatments. Chemicals were of highest purity (Sigma-Aldrich Co., St. Louis, MO, USA). To prepare growth regulators stock solutions, both IAA and BAP were dissolved in $80 \%$ $(\mathrm{v} / \mathrm{v})$ ethanol. No surfactants were used. Ten plants, either climbing, creeping or hanging, randomly distributed within each greenhouse block, were sprayed with each of the 16 growth regulators combinations tested.

At $0,60,90$, and 120 days after transplanting, two plants per block treated with each combination of growth regulators under each training system were destructively sampled. The number of leaves was recorded, and individual leaf area was determined using a LICOR 3000A automatic leaf area meter (LI-COR, Inc., Lincoln, NE, USA). Fresh weights (FW) of the different aerial parts i.e. leaf blades, petioles, and stems on each plant were determined. Dry weights (DW) were obtained after drying aerial parts and roots to constant weight at $80^{\circ} \mathrm{C}$ for 96 hours.

The relative rate of leaf area expansion (RLAE) was calculated as the slope of the regression of the natural logarithm $(\ln )$ of total leaf area versus time (in days). The rate of leaf appearance (RLA) was calculated as the slope of the number of visible leaves (including unrolled ones $>1 \mathrm{~cm}$ ) versus time (in weeks). Relative growth rate (RGR) was calculated as the slope of the regression of the $\ln$ DW (whole plant) versus time (in days). Mean net assimilation rate (NAR) was calculated as:

$$
N A R=\frac{k_{w} W_{0 e^{k \omega t}}}{A_{0 e^{k a t}}}
$$

where $\mathrm{W}_{0}$ : extrapolated value of total DW (g) at time zero; $\mathrm{k}_{\mathrm{w}}$ : RGR $\left(\right.$ days $\left.^{-1}\right) ; A_{0}$ : extrapolated value of leaf area $\left(\mathrm{cm}^{2}\right)$ at time zero; $\mathrm{k}_{\mathrm{a}}$ : RLAE $\left(d^{-1}\right)$; t: time (days) at the midpoint of the experimental period and e: base of natural logarithm.

Mean leaf area ratio (LAR) was calculated as:

$$
L A R=\frac{k_{w}}{N A R}
$$

Since in most treatments plant biomass accumulation approached a plateau towards the end of the experiment, the last sampling (120 days after transplant) was not included for performing this analysis, which is best suited for plants growing exponentially.

Specific leaf area (SLA) was calculated as the ratio of individual leaf area to leaf DW (average of all plant leaves).

The allometric coefficients between root and shoot were calculated as the slope $(\beta)$ of the straight-line regression of natural logarithm root DW versus natural logarithm shoot DW.

The net photosynthetic rate was measured at ambient $\mathrm{O}_{2}$ and $\mathrm{CO}_{2}$ concentrations at a saturating photon flux density $(>1,700 \mu \mathrm{mol}$ photons $\mathrm{m}^{-2} \mathrm{~s}^{-1}$ ) between 11.30-13.00 $\mathrm{h}$ on a sunny day just before final harvest. The youngest fully expanded leaf on three plants from each hormone treatment was selected for measurements, which were performed using a portable LICOR LI6200 photosynthetic system (LI-COR Inc., Lincoln, NE, USA).

Samples of young fully expanded leaves were collected to examine leaf anatomy i.e. overall leaf thickness, thickness of the mesophyll and the epidermal layers and volume of intercellular spaces, on the final harvest (120 days from transplanting). Tissue from the middle region of the lamina was fixed in a mixture of $70 \%$ ethanol, $5 \%$ formalin, $5 \%$ glacial acetic acid, and $20 \%$ distilled water prior to dehydration in an ethanol and tert-butyl alcohol series. Samples were sectioned at 10$20 \mu \mathrm{m}$ thick on a rotary microtome and stained with safranin-crystal violet-fast green. Data presented are the means of three leaves per treatment using ten leaf cross-sections per leaf. Quantitative anatomical data were obtained using Image Pro Express version 6.0 (Media Cybernetics, MD, USA).

The experiment was arranged in a three-way factorial design with four concentrations of IAA, four concentrations of BAP and three plant training systems. Data were subjected to three-way analysis of variance (ANOVA) using STATISTICA 8 software, after checking ANOVA assumptions and means were separated using Tukey's test. Least significant differences (LSD) values were calculated.

\section{RESULTS AND DISCUSSION}

At the end of the experiment, climbing plants (Figure 1A) had higher FW than creeping or hanging ones (Figure 1B and $\mathrm{C}$, respectively). The application of IAA or BAP at any concentration, either in single or combined manner, led to a significant increase in final FW 
in creeping and hanging plants, but not in climbing ones. However, in creeping plants untreated with IAA, the higher BAP doses appeared to be supra-optimal (Figure 1B).

There were no significant differences in dry matter content among training systems or hormone treatments (data not shown). Average values (\%) were $7.828 \pm 0.116,7.157 \pm 0.190,6.643 \pm 0.152$ and $8.443 \pm 0.170$ for roots, stems, petioles and leaves respectively.

In untreated controls, climbing plants had significantly higher DW-based RGR than either creeping or hanging ones. RGR for climbing plants was about $20 \%$ higher than for creeping plants, which in turn had about $15 \%$ higher RGR than hanging plants (Table 1). Single IAA or BAP sprays at either 5 or $50 \mathrm{mg} \mathrm{L}^{-1}$ significantly increased RGR of creeping plants, while $100 \mathrm{mg} \mathrm{L}^{-1}$ appeared to be a supra-optimal concentration for both hormones. In hanging plants, single hormone applications increased RGR at all concentrations tested, but maximum promotion was found when either IAA or BAP were applied at 50 $\mathrm{mg} \mathrm{L}^{-1}$. Combined hormone application in all combinations promoted RGR of creeping plants. On the other hand, in hanging plants, the most effective hormone combinations were the 50100 and $100-100 \mathrm{mg} \mathrm{L}^{-1}$ IAA-BAP treatments, although several other treatments also had an effect on RGR. No growth promotion was observed in the 5-50, 5-100 and 50-5 $\mathrm{mg} \mathrm{L}^{-1}$ IAA-BAP treatments. On the other hand, growth regulators applications on climbing plants resulted in a significantly decreased RGR in almost every IAABAP combination tested (of about $-20 \%$ in most cases), with the sole exception of $100-50 \mathrm{mg} \mathrm{L}^{-1}$ IAA-BAP treatment in which no significant RGR decrease was observed (Table 1).

In untreated controls, differences in RGR among training systems could be attributed more due to differences in NAR than to variation in LAR, although differences in NAR between climbing and creeping plants were not significant. Similarly, growth regulatorsdriven decrease in RGR of climbing plants was generally associated with a decrease in NAR, and conversely, the increase in RGR of growth regulatorstreated creeping or hanging plants was associated with a significant increase in NAR. Variation in LAR was in general low, climbing plants tend to present higher values than either creeping or hanging ones. LAR was rather unaffected by growth regulator treatments but in the few treatments in which significant growth regulators effects were found (i.e., 50-100 and 100-100 mg L-1 IAA-BAP treatments in hanging plants) a decrease response was observed (Table 1).

The root versus shoot allometric analysis of untreated controls showed a trend for higher root $v s$. shoot $\beta$ coefficient (which indicates lower DW partitioning to shoots) when departure from the upward growing position, being $\beta$ coefficient values of hanging plants about $12.2 \%$ higher than that of climbing ones (Table 2). Single IAA or BAP application resulted in decreased $\beta$ coefficient values under all training systems, but especially in hanging plants, in which values

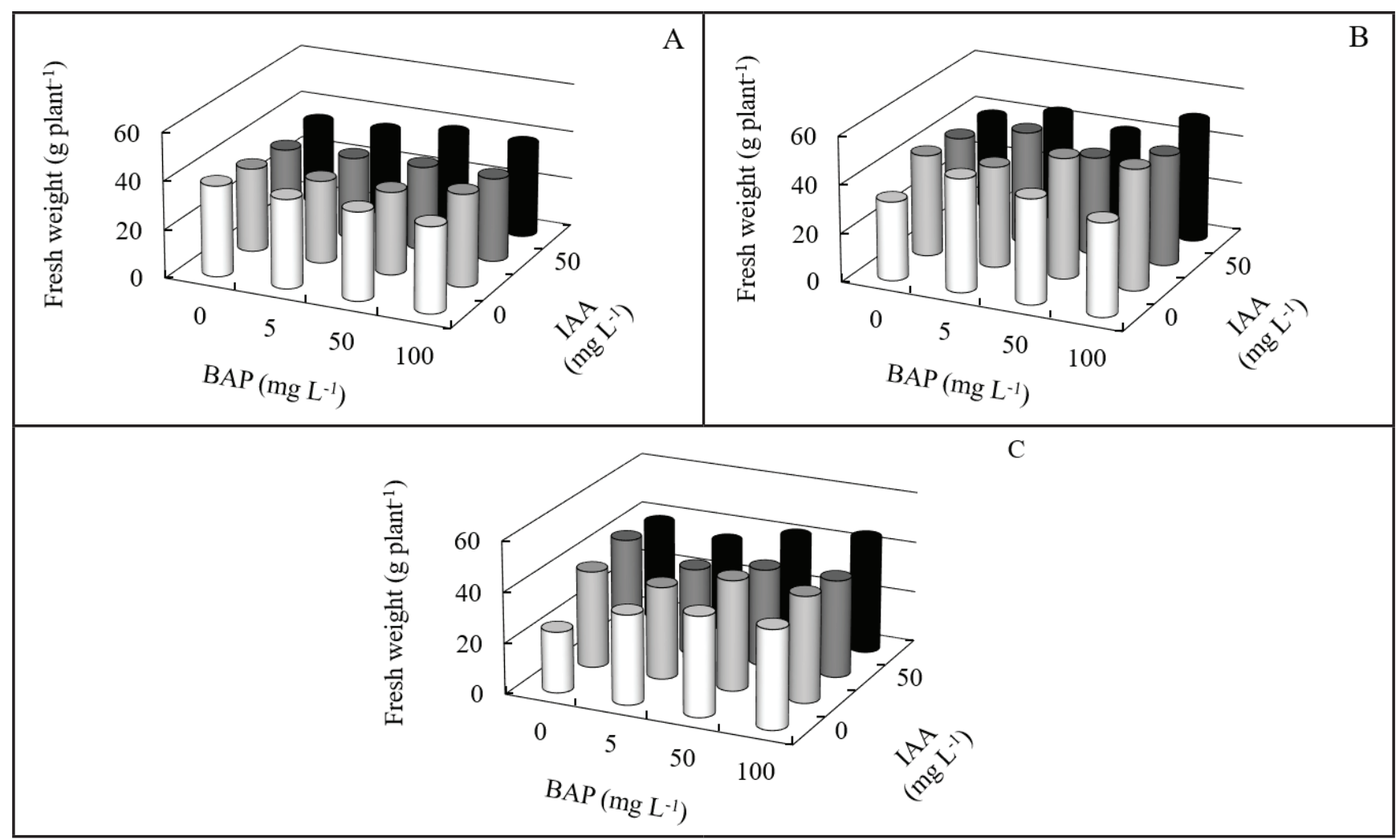

Figure 1. Fresh weight at the end of experiments (120 days from transplanting) of E. aureum plants sprayed with BAP at either $0,5,50$ or $100 \mathrm{mg} \mathrm{L}^{-1}$ on plants previously sprayed with IAA at $0,5,50$ or $100 \mathrm{mg} \mathrm{L}^{-1}$. Plants were grown under climbing (A), creeping (B) or hanging (C) training systems. Buenos Aires, UBA, 2008. 


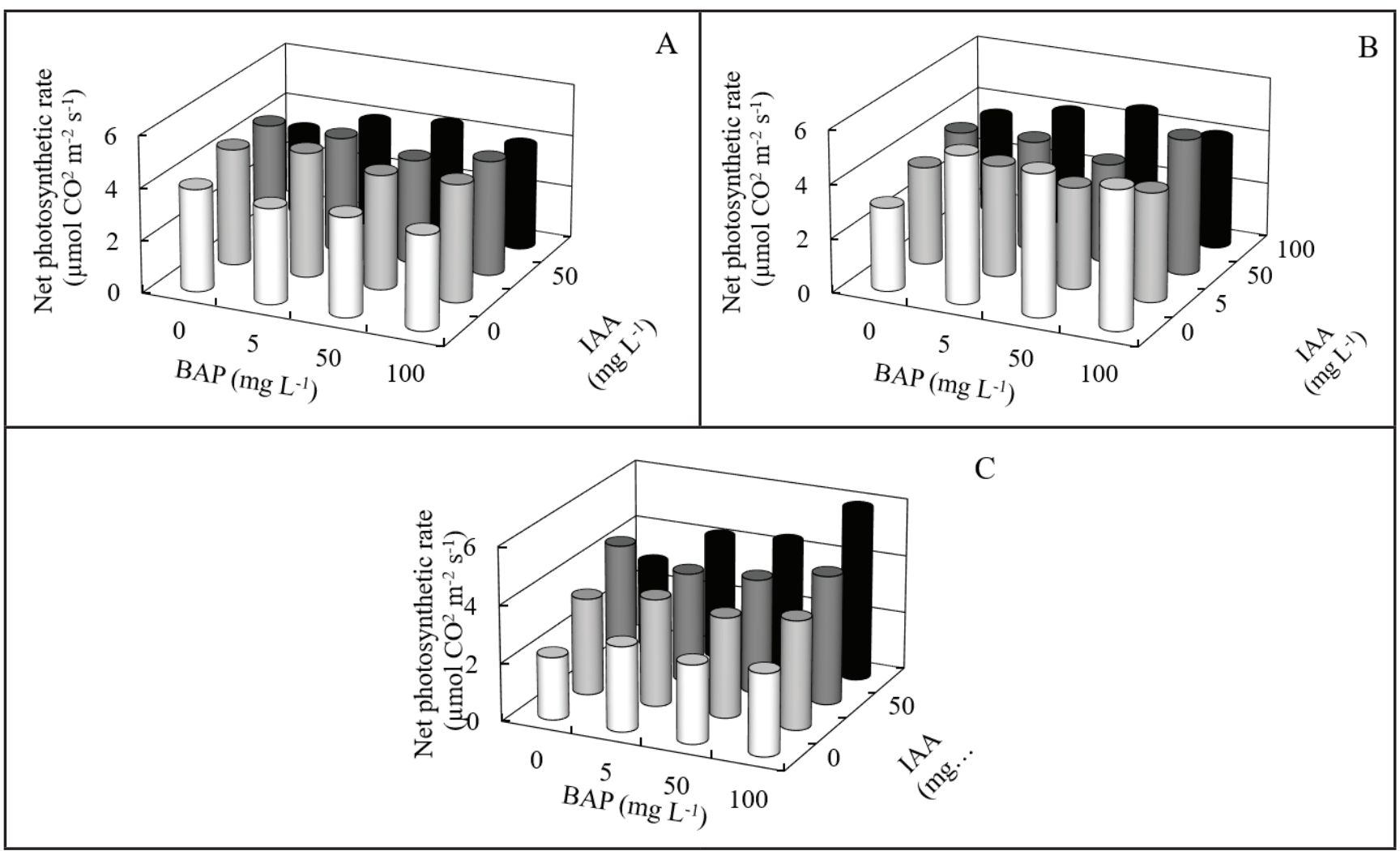

Figure 2. Net photosynthetic rate at the end of the experiments (120 days from transplanting) of E. aureum plants sprayed with BAP at either $0,5,50$ or $100 \mathrm{mg} \mathrm{L}^{-1}$ on plants previously sprayed with IAA at $0,5,50$ or $100 \mathrm{mg} \mathrm{L}^{-1}$. Plants were grown under climbing (A), creeping (B) and hanging (C) training systems. Buenos Aires, UBA, 2008.

decreased by more than $25 \%$. Under any training system, combined growth regulators treatments produced low $\beta$ coefficient values, in comparison with untreated controls (Table 2).

The net photosynthetic rate of young, fully expanded leaves of untreated plants showed a similar pattern to that of biomass allocation, this is, higher values in climbing plants than in creeping ones, and higher values in creeping plants than in hanging ones (Figure 2A-C).

In climbing plants, IAA or BAP in either single or combined application did not result in a promotion of photosynthesis (Figure 2A). Conversely, in creeping and hanging plants, a significant increase of net photosynthetic rate was observed when exogenous IAA and BAP, either in single or combined manner, were applied. The promotive effect of growth regulators were maximum in hanging plants, particularly at the highest IAA+BAP doses, which resulted in a two-fold increase of the net photosynthetic rate over untreated controls (Figure 2C).
Trends for plant total leaf area of untreated controls at the end of the experiment, as well as for the relative rate of leaf expansion (RLAE), were similar to those found for FW and DW accumulation, this is, significantly higher values for climbing plants than for creeping or hanging ones (Table 3 ). Both larger individual leaf area and higher rate of leaf appearance in climbing plants than in either creeping or hanging ones accounted for such differences. Conversely, SLA values of climbing plants were lower than in creeping ones, and they were also lower in creeping than in hanging ones.

In creeping plants, single BAP sprays at 5 or $50 \mathrm{mg} \mathrm{L}^{-1}$ resulted in increased values, being the concentration of 100 $\mathrm{mg} \mathrm{L}^{-1}$ supra-optimal, while in hanging plants all concentrations were promotive (particularly the highest one). On the other hand, IAA sprays on creeping plants significantly promoted total leaf area only at the lowest concentration tested $\left(5 \mathrm{mg} \mathrm{L}^{-1}\right)$; while on hanging plants, all IAA concentrations were similarly effective. Combined IAA+BAP treatments varied in effectiveness in creeping plants, being either promotive or neutral, while in hanging plants all growth regulators combinations were promotive (particularly the highest dose tested, i.e. $100-100 \mathrm{mg} \mathrm{L}^{-1}$ IAA-BAP treatment).

Up to a large extent, differences in RLAE among training systems for each growth regulators combinations treatment accompanied those found for total leaf area at the end of the experiment. In climbing plants, the growth regulators-induced decrease in both variables measuring total leaf area accumulation, could be ascribed to a reduced RLA rather than to a decrease in individual leaf area, since growth regulators sprays at any combination in comparison with untreated controls, did not significantly affect the latter. In contrast, in creeping and hanging plants, both increased individual leaf area and RLA contributed, in general, to the promotion of leaf area accumulation by IAA and/or BAP. In particular, both 
Table 1. Relative growth rate (RGR), net assimilation rate (NAR) and leaf area ratio (LAR) values in climbing, creeping or hanging E. aureum plants sprayed with IAA $\left(0,5,50\right.$ or $\left.100 \mathrm{mg} \mathrm{L}^{-1}\right)$ followed one week later by BAP (0, 5, 50 and or $\left.100 \mathrm{mg} \mathrm{L}^{-1}\right)$. Buenos Aires, UBA, 2008.

\begin{tabular}{|c|c|c|c|c|c|c|c|}
\hline $\begin{array}{l}\text { IAA-BAP } \\
\left(\mathrm{mg} \mathrm{L}^{-1}\right)\end{array}$ & $\begin{array}{c}\text { RGR } \\
\left(\mathrm{g} \mathrm{g}^{-1} \text { day }^{-1}\right)\end{array}$ & $\begin{array}{l}\text { NAR }\left[\mathrm{g} \mathrm{cm}^{-2}\right. \\
\left.\text { day }^{-1}\left(\mathbf{x}_{10}^{-5}\right)\right]\end{array}$ & $\begin{array}{c}\text { LAR } \\
\left(\mathrm{cm}^{2} \mathbf{g}^{-1}\right)\end{array}$ & $\begin{array}{c}\text { IAA-BAP } \\
\left(\mathrm{mg} \mathrm{L}^{-1}\right)\end{array}$ & $\begin{array}{c}\text { RGR } \\
\left(\mathrm{g} \mathrm{g}^{-1} \text { day }^{-1}\right)\end{array}$ & $\begin{array}{l}\text { NAR }\left[\mathrm{g} \mathrm{cm}^{-2}\right. \\
\text { day }^{-1}\left(\begin{array}{ll}\mathbf{x} & \left.\left.10^{-5}\right)\right]\end{array}\right.\end{array}$ & $\begin{array}{c}\text { LAR } \\
\left(\mathrm{cm}^{2} \mathrm{~g}^{-1}\right)\end{array}$ \\
\hline 0-0 & & & & $50-0$ & & & \\
\hline Climbing & $0.0211 \mathrm{aA}$ & $9.74 \mathrm{aA}$ & $216.39 \mathrm{aA}$ & Climbing & $0.0161 \mathrm{bB}$ & $7.31 \mathrm{bB}$ & $220.21 \mathrm{aA}$ \\
\hline Creeping & $0.0177 \mathrm{bB}$ & $9.20 \mathrm{bA}$ & $192.02 \mathrm{aA}$ & Creeping & $0.0202 \mathrm{aA}$ & $11.87 \mathrm{aA}$ & $170.20 \mathrm{aB}$ \\
\hline Hanging & $0.0153 \mathrm{cC}$ & $7.62 \mathrm{bB}$ & $200.78 \mathrm{aA}$ & Hanging & $0.0199 \mathrm{aA}$ & $11.12 \mathrm{aA}$ & $179.00 \mathrm{bB}$ \\
\hline $0-5$ & & & & $50-5$ & & & \\
\hline Climbing & $0.0172 \mathrm{~b}$ & $7.71 \mathrm{bB}$ & $223.14 \mathrm{aA}$ & Climbing & $0.0174 \mathrm{bB}$ & $7.48 \mathrm{bB}$ & $232.48 \mathrm{aA}$ \\
\hline Creeping & $0.0241 \mathrm{aA}$ & $13.03 \mathrm{aA}$ & $185.03 \mathrm{aB}$ & Creeping & $0.0206 \mathrm{aA}$ & $11.68 \mathrm{aA}$ & $176.44 \mathrm{aB}$ \\
\hline Hanging & $0.0174 \mathrm{bB}$ & $8.93 \mathrm{bB}$ & $194.82 \mathrm{aB}$ & Hanging & $0.0145 \mathrm{cC}$ & $7.30 \mathrm{cB}$ & $198.74 \mathrm{aB}$ \\
\hline $0-50$ & & & & $50-50$ & & & \\
\hline Climbing & $0.0177 \mathrm{bB}$ & $7.63 \mathrm{bB}$ & $231.90 \mathrm{aA}$ & Climbing & $0.0169 \mathrm{bB}$ & $7.29 \mathrm{bB}$ & $231.76 \mathrm{aA}$ \\
\hline Creeping & $0.0194 \mathrm{aA}$ & $10.22 \mathrm{bA}$ & $189.84 \mathrm{aB}$ & Creeping & $0.0198 \mathrm{aA}$ & $11.14 \mathrm{aA}$ & $177.75 \mathrm{aB}$ \\
\hline Hanging & $0.0192 \mathrm{aA}$ & $10.20 \mathrm{aA}$ & $188.31 \mathrm{aB}$ & Hanging & $0.0163 \mathrm{bB}$ & $7.98 \mathrm{bB}$ & $204.30 \mathrm{aB}$ \\
\hline $0-100$ & & & & $50-100$ & & & \\
\hline Climbing & $0.0176 \mathrm{bA}$ & $7.80 \mathrm{bB}$ & $225.74 \mathrm{aA}$ & Climbing & $0.0178 \mathrm{bB}$ & $7.61 \mathrm{bB}$ & $233.95 \mathrm{aA}$ \\
\hline Creeping & $0.0180 \mathrm{bA}$ & $9.13 \mathrm{bA}$ & $197.16 \mathrm{aB}$ & Creeping & $0.0200 \mathrm{aA}$ & $10.69 \mathrm{bA}$ & $187.17 \mathrm{aB}$ \\
\hline Hanging & $0.0185 \mathrm{bA}$ & $9.65 \mathrm{aA}$ & $191.77 \mathrm{aB}$ & Hanging & $0.0169 \mathrm{bB}$ & $8.16 \mathrm{bB}$ & $207.08 \mathrm{aB}$ \\
\hline $5-0$ & & & & $100-0$ & & & \\
\hline Climbing & $0.0173 \mathrm{bA}$ & $7.73 \mathrm{bB}$ & $223.83 \mathrm{aA}$ & Climbing & $0.0165 \mathrm{bA}$ & $7.13 \mathrm{bB}$ & $231.53 \mathrm{aA}$ \\
\hline Creeping & $0.0198 \mathrm{aA}$ & $10.26 \mathrm{bA}$ & $193.04 \mathrm{aB}$ & Creeping & $0.0183 \mathrm{bA}$ & $9.37 \mathrm{bA}$ & $195.35 \mathrm{aB}$ \\
\hline Hanging & $0.0176 \mathrm{bA}$ & $9.03 \mathrm{bA}$ & $194.98 \mathrm{aB}$ & Hanging & $0.0169 \mathrm{bA}$ & $8.39 \mathrm{bA}$ & $201.36 \mathrm{aB}$ \\
\hline $5-5$ & & & & $100-5$ & & & \\
\hline Climbing & $0.0159 \mathrm{bB}$ & $7.01 \mathrm{bB}$ & $226.72 \mathrm{aA}$ & Climbing & $0.0181 \mathrm{bB}$ & $7.95 \mathrm{bB}$ & $227.44 \mathrm{aA}$ \\
\hline Creeping & $0.0194 \mathrm{aA}$ & $10.82 \mathrm{bA}$ & $179,25 \mathrm{aB}$ & Creeping & $0.0206 \mathrm{aA}$ & $12.04 \mathrm{aA}$ & $171.07 \mathrm{aB}$ \\
\hline Hanging & $0.0170 \mathrm{bB}$ & $8.43 \mathrm{bB}$ & $201.76 \mathrm{aA}$ & Hanging & $0.0175 \mathrm{bB}$ & $8.45 \mathrm{bB}$ & $207.20 \mathrm{aA}$ \\
\hline $5-50$ & & & & $100-50$ & & & \\
\hline Climbing & $0.0160 \mathrm{bB}$ & $6.75 \mathrm{bB}$ & $236.91 \mathrm{aA}$ & Climbing & $0.0194 \mathrm{aA}$ & $9.28 \mathrm{aB}$ & $209.03 \mathrm{aA}$ \\
\hline Creeping & $0.0205 \mathrm{aA}$ & $11.20 \mathrm{aA}$ & $182.97 \mathrm{aB}$ & Creeping & $0.0202 \mathrm{aA}$ & $10.72 \mathrm{bA}$ & $188.52 \mathrm{aB}$ \\
\hline Hanging & $0.0137 \mathrm{cC}$ & $6.21 \mathrm{cB}$ & $220.48 \mathrm{aA}$ & Hanging & $0.0198 \mathrm{aA}$ & $11.12 \mathrm{aA}$ & $178.06 \mathrm{bB}$ \\
\hline $5-100$ & & & & $100-100$ & & & \\
\hline Climbing & $0.0181 \mathrm{bB}$ & $8.15 \mathrm{bB}$ & $222.16 \mathrm{aA}$ & Climbing & $0.0170 \mathrm{bB}$ & $7.21 \mathrm{bB}$ & $235.90 \mathrm{aA}$ \\
\hline Creeping & $0.0210 \mathrm{aA}$ & $12.28 \mathrm{aA}$ & $170.97 \mathrm{aB}$ & Creeping & $0.0224 \mathrm{aA}$ & $13.10 \mathrm{aA}$ & $170.97 \mathrm{aB}$ \\
\hline Hanging & $0.0136 \mathrm{cC}$ & $6.42 \mathrm{cC}$ & $211.94 \mathrm{aA}$ & Hanging & $0.0225 \mathrm{aA}$ & $13.06 \mathrm{aA}$ & $172.33 \mathrm{bB}$ \\
\hline
\end{tabular}

Different lowercase letters indicate significant differences for each growth parameter between AIA-BAP concentrations for the same training system while different capital letters indicate significant differences among training systems for each AIA-BAP concentration ( $<<0.05$ )

growth regulators promoted individual leaf area of hanging plants over 100\% of untreated controls in most hormone combinations.

On the other hand, untreated creeping and hanging plants showed higher SLA values (about 15\% and $25 \%$ respectively) than climbing ones. Growth regulators treatments generally had no significant effect on SLA values of climbing plants. Conversely, most growth regulators combinations (i.e., except 5-50, 5-100 $\mathrm{mg} \mathrm{L}^{-1}$ and 50-5 IAABAP $\mathrm{mg} \mathrm{L}^{-1}$ treatments) significantly decreased SLA of hanging plants. In creeping plants, results were more variable: while in general no significant differences were observed between growth regulators-sprayed plants and untreated controls, one growth regulator combination increased SLA while another combination decreased it (50-50 and 5-5 $\mathrm{mg} \mathrm{L}^{-1}$ IAA-BAP, respectively) (Table 3).

Control, untreated climbing plants had thicker leaves than creeping and hanging ones. Single or combined IAA- 
BAP sprays increased leaf thickness particularly in hanging plants sprayed with BAP at 5 or $50 \mathrm{mg} \mathrm{L}^{-1}$, or with IAA at $5 \mathrm{mg} \mathrm{L}^{-1}$, although a promotive effect was also observed in creeping ones. On the other hand, no significant effect could be observed in climbing plants. As a consequence of the differential effect of growth regulators among training systems, little differences in leaf thickness could be observed in leaves from sprayed plants, especially under IAA+BAP combinations at the higher doses (Figure 3A).

In untreated climbing plants, the epidermal cell layer represented a larger fraction of leaf cross-section than in either creeping or hanging ones. Growth regulators applications tended to reduce this contribution in climbing plants and to increase it in hanging ones, while no clear trend was observed in creeping plants (Figure 3B-D). The intercellular space fraction occupied a relatively low proportion of leaf cross-sections (i.e., $8 \%$ to $18 \%$ ) in untreated controls, irrespective of the training system. In most cases, growth regulators supply led to an increase in this fraction, particularly in climbing and creeping plants. On the other hand, no clear trends regarding the parenchymatous layer were found.

Steinitz \& Hagiladi (1987) and Steinitz et al. (1992) reported the climbing plants of 'Golden pothos' and other ornamental Araceae plants develop larger leaves than hanging plants. In the present work we show that leaves from climbing E. aureum plants are not only larger but also thicker, and with a lower SLA, than those from hanging ones, and that similar differences can be found when creeping plants are compared to hanging ones, the latter displaying the smallest leaves with the largest SLA values (Table 3 ). These differences ultimately lead to a decreasing foliage production (i.e., RLAE) with departure from upward growth position. These effects were also accompanied with an increasing dry mass partitioning towards the root system, from climbing to hanging plants (Table 2). However, an even more important effect of training system on plant performance was that of carbon assimilation, being both the calculated NAR and measured photosynthetic rates higher in climbing plants than in creeping ones, and higher in creeping plants than in hanging ones (Table 3, Figure 2). This effect led to important differences among training systems in RGR, which decreased together with departure from upward growth position (Table 1).

Auxin and/or cytokinin-sprays on either creeping or hanging plants led to larger leaf size and total leaf area production (Table 3) in parallel with a decreased dry mass partitioning to roots (Table 2). Growth regulatorstreated plants also showed higher RGR values, which could be explained mainly because of a strong promotion in NAR by both auxin and cytokinin. In general, single-growth regulators effects were maximum at lower growth regulators concentrations, with higher doses resulting supra optimal in many cases. These results are in good agreement with previous work on creeping $E$. aureum plants (Di Benedetto et al., 2015a, b). Growth regulators-driven promotion of carbon fixation per unit leaf area may be, in part,explained by changes in the leaf anatomy, including thicker leaves

Table 2. Allometric analysis (ln Root dry weight $=\alpha+\beta x \ln$ Shoot dry weight) for climbing, creeping or hanging $E$. aureum plants sprayed with IAA at $0,5,50$ or $100 \mathrm{mg} \mathrm{L}^{-1}$ followed one week later by BAP at $0,5,50$ and or $100 \mathrm{mg} \mathrm{L}^{-1}$. Buenos Aires, UBA, 2008.

\begin{tabular}{|c|c|c|c|c|c|c|}
\hline \multirow{3}{*}{$\begin{array}{l}\text { IAA-BAP } \\
\left(\mathrm{mg} \mathrm{L}^{-1}\right)\end{array}$} & \multicolumn{6}{|c|}{ Roots vs. shoots } \\
\hline & \multicolumn{2}{|c|}{ Climbing } & \multicolumn{2}{|c|}{ Creeping } & \multicolumn{2}{|c|}{ Hanging } \\
\hline & $\beta$ & $\mathbf{r}^{2}$ & $\beta$ & $\mathbf{r}^{2}$ & $\beta$ & $\mathbf{r}^{2}$ \\
\hline $0-0$ & $1.110 \mathrm{aB}$ & 0.932 & $1.188 \mathrm{aA}$ & 0.865 & $1.246 \mathrm{aA}$ & 0.905 \\
\hline $0-5$ & $1.013 \mathrm{bA}$ & 0.914 & $1.145 \mathrm{aA}$ & 0.927 & $0.876 \mathrm{cB}$ & 0.732 \\
\hline $0-50$ & $0.976 \mathrm{bA}$ & 0.891 & $1.056 \mathrm{bA}$ & 0.922 & $0.936 \mathrm{cB}$ & 0.892 \\
\hline $0-100$ & $0.963 \mathrm{bA}$ & 0.854 & $0.992 \mathrm{bA}$ & 0.681 & $0.992 \mathrm{bA}$ & 0.917 \\
\hline $5-0$ & $1.086 \mathrm{cA}$ & 0.898 & $1.007 \mathrm{bA}$ & 0.941 & $1.076 \mathrm{bA}$ & 0.865 \\
\hline $5-5$ & $0.860 \mathrm{cB}$ & 0.954 & $0.965 \mathrm{bA}$ & 0.875 & $1.067 \mathrm{bA}$ & 0.871 \\
\hline $5-50$ & $0.887 \mathrm{cB}$ & 0.862 & $1.083 \mathrm{bA}$ & 0.928 & $0.929 \mathrm{cB}$ & 0.841 \\
\hline $5-100$ & $0.998 \mathrm{bA}$ & 0.927 & $1.049 \mathrm{bA}$ & 0.939 & $1.015 \mathrm{bA}$ & 0.831 \\
\hline $50-0$ & $0.995 \mathrm{bA}$ & 0.901 & $1.093 \mathrm{bA}$ & 0.892 & $0.993 \mathrm{bA}$ & 0.905 \\
\hline $50-5$ & $0.948 \mathrm{bA}$ & 0.870 & $1.018 \mathrm{bA}$ & 0.925 & $1.022 \mathrm{bA}$ & 0.823 \\
\hline $50-50$ & $0.860 \mathrm{cA}$ & 0.837 & $1.000 \mathrm{Ab}$ & 0.899 & $0.764 \mathrm{dA}$ & 0.821 \\
\hline $50-100$ & $0.847 \mathrm{cB}$ & 0.821 & $1.028 \mathrm{bA}$ & 0.920 & $0.972 \mathrm{bA}$ & 0.888 \\
\hline $100-0$ & $1.041 \mathrm{bA}$ & 0.897 & $1.066 \mathrm{bA}$ & 0.925 & $0.935 \mathrm{cB}$ & 0.886 \\
\hline $100-5$ & $1.002 \mathrm{bA}$ & 0.904 & $1.071 \mathrm{bA}$ & 0.914 & $0.877 \mathrm{cB}$ & 0.882 \\
\hline $100-50$ & $0.952 \mathrm{bA}$ & 0.857 & $0.792 \mathrm{cB}$ & 0.651 & $0.942 \mathrm{cA}$ & 0.909 \\
\hline $100-100$ & $0.883 \mathrm{cB}$ & 0.873 & $1.044 \mathrm{bA}$ & 0.947 & $0.997 \mathrm{bA}$ & 0.951 \\
\hline
\end{tabular}

The straight-line regression $\alpha$ coefficient are not shown. All slopes were statistically significant $(\mathrm{P}<0.001)$. 
Table 3. Plant total leaf area, mean individual leaf area, relative leaf area rate (RLAE), rate of leaf appearance (RLA) and specific leaf area (SLA) in climbing, creeping or hanging E. aureum plants sprayed with IAA at $0,5,50$ or $100 \mathrm{mg} \mathrm{L}^{-1}$ followed one week later by BAP at 0 , 5, 50 and or $100 \mathrm{mg} \mathrm{L}^{-1}$. Buenos Aires, UBA, 2008.

\begin{tabular}{|c|c|c|c|c|c|}
\hline 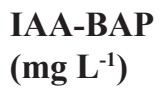 & $\begin{array}{l}\text { Total leaf area } \\
\left(\mathrm{cm}^{2} \text { plant }^{-1}\right)\end{array}$ & $\begin{array}{l}\text { Individual leaf area } \\
\left(\mathrm{cm}^{2} \text { leaf }^{-1}\right)\end{array}$ & $\begin{array}{c}\text { RLAE } \\
\left(\mathrm{cm}^{2} \mathbf{c m}^{-2} \text { day }^{-1}\right)\end{array}$ & $\begin{array}{c}\text { RLA } \\
\left(\text { (leaves week }^{-1}\right)\end{array}$ & $\begin{array}{c}\text { SLA } \\
\left(\mathrm{cm}^{2} \mathrm{~g}^{-1}\right)\end{array}$ \\
\hline \multicolumn{6}{|l|}{$0-0$} \\
\hline Climbing & $539.47 \mathrm{aA}$ & $77.17 \mathrm{aA}$ & $0.0146 \mathrm{aA}$ & $1.074 \mathrm{aA}$ & $460.58 \mathrm{aC}$ \\
\hline Creeping & $357.81 \mathrm{bB}$ & $45.83 \mathrm{bB}$ & $0.0116 \mathrm{cB}$ & $0.870 \mathrm{cB}$ & $521.13 \mathrm{bB}$ \\
\hline Hanging & $262.08 \mathrm{cC}$ & $40.80 \mathrm{cB}$ & $0.0088 \mathrm{dC}$ & $0.894 \mathrm{cB}$ & $581.18 \mathrm{aA}$ \\
\hline \multicolumn{6}{|l|}{$0-5$} \\
\hline Climbing & $423.67 \mathrm{bA}$ & $73.18 \mathrm{aB}$ & $0.0123 \mathrm{bB}$ & $0.981 \mathrm{bB}$ & $492.42 \mathrm{aA}$ \\
\hline Creeping & $488.58 \mathrm{aA}$ & $67.33 \mathrm{aB}$ & $0.0165 \mathrm{aA}$ & $1.284 \mathrm{aA}$ & $479.99 \mathrm{bA}$ \\
\hline Hanging & $347.19 \mathrm{bB}$ & $83.33 \mathrm{aA}$ & $0.0105 \mathrm{bC}$ & $1.051 \mathrm{bB}$ & $515.54 \mathrm{bA}$ \\
\hline \multicolumn{6}{|l|}{$0-50$} \\
\hline Climbing & $436.21 \mathrm{bA}$ & $76.41 \mathrm{aB}$ & $0.0133 \mathrm{aA}$ & $0.970 \mathrm{bB}$ & $471.29 \mathrm{aB}$ \\
\hline Creeping & $408.87 \mathrm{bA}$ & $71.70 \mathrm{aB}$ & $0.0122 \mathrm{cB}$ & $1.081 \mathrm{bA}$ & $524.83 \mathrm{bA}$ \\
\hline Hanging & $370.66 \mathrm{bB}$ & $90.46 \mathrm{aA}$ & $0.0118 \mathrm{bB}$ & $1.148 \mathrm{aA}$ & $494.90 \mathrm{cB}$ \\
\hline \multicolumn{6}{|l|}{$0-100$} \\
\hline Climbing & $412.15 \mathrm{bA}$ & $68.48 \mathrm{aB}$ & $0.0128 \mathrm{bA}$ & $0.933 \mathrm{bB}$ & $459.68 \mathrm{aB}$ \\
\hline Creeping & $389.62 \mathrm{bB}$ & $58.50 \mathrm{aB}$ & $0.0113 \mathrm{cB}$ & $1.078 \mathrm{bA}$ & $554.34 \mathrm{bA}$ \\
\hline Hanging & $406.01 \mathrm{aA}$ & $92.91 \mathrm{aA}$ & $0.0114 \mathrm{bB}$ & $1.047 \mathrm{bA}$ & $530.76 \mathrm{bA}$ \\
\hline \multicolumn{6}{|l|}{ 5-0 } \\
\hline Climbing & $393.10 \mathrm{bA}$ & $66.72 \mathrm{aA}$ & $0.0123 \mathrm{bA}$ & $0.926 \mathrm{bB}$ & $483.64 \mathrm{aA}$ \\
\hline Creeping & $459.94 \mathrm{aA}$ & $70.83 \mathrm{aA}$ & $0.0128 \mathrm{cA}$ & $1.133 \mathrm{bA}$ & $528.07 \mathrm{bA}$ \\
\hline Hanging & $325.25 \mathrm{bB}$ & $78.64 \mathrm{aA}$ & $0.0106 \mathrm{bB}$ & $1.022 \mathrm{bB}$ & $507.17 \mathrm{bA}$ \\
\hline \multicolumn{6}{|l|}{$5-5$} \\
\hline Climbing & $388.20 \mathrm{bA}$ & $81.38 \mathrm{aA}$ & $0.0112 \mathrm{cA}$ & $0.898 \mathrm{cB}$ & $491.29 \mathrm{aA}$ \\
\hline Creeping & $357.36 \mathrm{bA}$ & $71.28 \mathrm{aA}$ & $0.0113 \mathrm{dA}$ & $1.101 \mathrm{bA}$ & $407.43 \mathrm{cB}$ \\
\hline Hanging & $329.43 \mathrm{bA}$ & $84.02 \mathrm{aA}$ & $0.0106 \mathrm{bA}$ & $1.050 \mathrm{bA}$ & $510.22 \mathrm{bA}$ \\
\hline \multicolumn{6}{|l|}{$5-50$} \\
\hline Climbing & $404.69 \mathrm{bA}$ & $71.74 \mathrm{aA}$ & $0.0119 \mathrm{bA}$ & $0.953 \mathrm{bB}$ & $488.74 \mathrm{aB}$ \\
\hline Creeping & $421.26 \mathrm{aA}$ & $75.34 \mathrm{aA}$ & $0.0128 \mathrm{cA}$ & $1.144 \mathrm{bA}$ & $498.56 \mathrm{bB}$ \\
\hline Hanging & $378.62 \mathrm{bB}$ & $79.48 \mathrm{aA}$ & $0.0086 \mathrm{~dB}$ & $0.978 \mathrm{bB}$ & $582.57 \mathrm{aA}$ \\
\hline \multicolumn{6}{|l|}{$5-100$} \\
\hline Climbing & $431.86 \mathrm{bA}$ & $70.95 \mathrm{aA}$ & $0.0132 \mathrm{aA}$ & $1.067 \mathrm{aB}$ & $455.39 \mathrm{aC}$ \\
\hline Creeping & $449.83 \mathrm{aA}$ & $68.19 \mathrm{aA}$ & $0.0123 \mathrm{cA}$ & $1.241 \mathrm{aA}$ & $517.95 \mathrm{bB}$ \\
\hline Hanging & $348.85 \mathrm{bB}$ & $75.59 \mathrm{aA}$ & $0.0079 \mathrm{~dB}$ & $0.889 \mathrm{cC}$ & $587.72 \mathrm{aA}$ \\
\hline \multicolumn{6}{|l|}{$50-0$} \\
\hline Climbing & $374.08 \mathrm{cA}$ & $62.82 \mathrm{aB}$ & $0.0110 \mathrm{cA}$ & $0.906 \mathrm{bB}$ & $481.18 \mathrm{aA}$ \\
\hline Creeping & $360.82 \mathrm{bA}$ & $68.38 \mathrm{aB}$ & $0.0114 \mathrm{dA}$ & $1.069 \mathrm{bA}$ & $510.12 \mathrm{bA}$ \\
\hline Hanging & $372.87 \mathrm{bA}$ & $84.28 \mathrm{aA}$ & $0.0117 \mathrm{bA}$ & $0.926 \mathrm{cB}$ & $486.08 \mathrm{cA}$ \\
\hline \multicolumn{6}{|l|}{$50-5$} \\
\hline Climbing & $424.68 \mathrm{bA}$ & $72.02 \mathrm{aB}$ & $0.0130 \mathrm{aA}$ & $1.030 \mathrm{aB}$ & $462.30 \mathrm{aB}$ \\
\hline Creeping & $423.55 \mathrm{aA}$ & $69.60 \mathrm{aB}$ & $0.0121 \mathrm{cA}$ & $1.160 \mathrm{bA}$ & $529.69 \mathrm{bA}$ \\
\hline Hanging & $325.71 \mathrm{bB}$ & $87.00 \mathrm{aA}$ & $0.0077 \mathrm{~dB}$ & $0.944 \mathrm{bB}$ & $563.81 \mathrm{aA}$ \\
\hline \multicolumn{6}{|l|}{$50-50$} \\
\hline Climbing & $402.07 \mathrm{bA}$ & $66.62 \mathrm{aB}$ & $0.0125 \mathrm{bA}$ & $1.000 \mathrm{aA}$ & $476.16 \mathrm{aC}$ \\
\hline Creeping & $385.64 \mathrm{bA}$ & $66.20 \mathrm{aB}$ & $0.0115 \mathrm{dA}$ & $1.056 \mathrm{bA}$ & $628.78 \mathrm{aA}$ \\
\hline Hanging & $321.45 \mathrm{bB}$ & $90.15 \mathrm{aA}$ & $0.0099 \mathrm{cB}$ & $0.944 \mathrm{bA}$ & $531.64 \mathrm{bB}$ \\
\hline
\end{tabular}


Table 3. Continuation

\begin{tabular}{|c|c|c|c|c|c|}
\hline $\begin{array}{l}\text { IAA-BAP } \\
\left(\mathrm{mg} \mathrm{L}^{-1}\right)\end{array}$ & $\begin{array}{l}\text { Total leaf area } \\
\left(\mathrm{cm}^{2} \text { plant }^{-1}\right)\end{array}$ & $\begin{array}{l}\text { Individual leaf area } \\
\qquad\left(\mathrm{cm}^{2} \operatorname{leaf}^{-1}\right)\end{array}$ & $\begin{array}{c}\text { RLAE } \\
\left(\mathrm{cm}^{2} \mathbf{c m}^{-2} \text { day }^{-1}\right)\end{array}$ & $\begin{array}{c}\text { RLA } \\
\left(\text { (leaves week }^{-1}\right)\end{array}$ & $\begin{array}{c}\text { SLA } \\
\left(\mathrm{cm}^{2} \mathrm{~g}^{-1}\right)\end{array}$ \\
\hline \multicolumn{6}{|l|}{$50-100$} \\
\hline Climbing & $473.79 \mathrm{bA}$ & $67.73 \mathrm{aB}$ & $0.0135 \mathrm{bA}$ & $1.009 \mathrm{aA}$ & $468.84 \mathrm{aB}$ \\
\hline Creeping & $437.87 \mathrm{aA}$ & $67.98 \mathrm{aB}$ & $0.0126 \mathrm{cA}$ & $1.074 \mathrm{bA}$ & $542.35 \mathrm{bA}$ \\
\hline Hanging & $331.88 \mathrm{bB}$ & $88.63 \mathrm{aA}$ & $0.0109 \mathrm{bB}$ & $0.978 \mathrm{bA}$ & $538.28 \mathrm{bA}$ \\
\hline \multicolumn{6}{|l|}{$100-0$} \\
\hline Climbing & $394.67 \mathrm{bA}$ & $66.02 \mathrm{aB}$ & $0.0121 \mathrm{bA}$ & $0.956 \mathrm{bA}$ & $506.13 \mathrm{aA}$ \\
\hline Creeping & $380.86 \mathrm{bA}$ & $66.84 \mathrm{aB}$ & $0.0113 \mathrm{cA}$ & $0.929 \mathrm{cA}$ & $522.55 \mathrm{bA}$ \\
\hline Hanging & $347.80 \mathrm{bA}$ & $87.81 \mathrm{aA}$ & $0.0105 \mathrm{bA}$ & $1.020 \mathrm{bA}$ & $547.55 \mathrm{bA}$ \\
\hline \multicolumn{6}{|l|}{$100-5$} \\
\hline Climbing & $434.65 \mathrm{bA}$ & $67.31 \mathrm{aB}$ & $0.0134 \mathrm{bA}$ & $0.972 \mathrm{bC}$ & $466.57 \mathrm{aB}$ \\
\hline Creeping & $377.41 \mathrm{bB}$ & $68.62 \mathrm{aB}$ & $0.0117 \mathrm{cB}$ & $1.203 \mathrm{aA}$ & $496.30 \mathrm{bA}$ \\
\hline Hanging & $360.86 \mathrm{bB}$ & $91.24 \mathrm{aA}$ & $0.0115 \mathrm{bB}$ & $1.120 \mathrm{aB}$ & $517.20 \mathrm{bA}$ \\
\hline \multicolumn{6}{|l|}{$100-50$} \\
\hline Climbing & $411.28 \mathrm{bA}$ & $61.99 \mathrm{aB}$ & $0.0136 \mathrm{bA}$ & $1.121 \mathrm{aA}$ & $458.01 \mathrm{aB}$ \\
\hline Creeping & $406.88 \mathrm{bA}$ & $69.94 \mathrm{aB}$ & $0.0128 \mathrm{cB}$ & $1.044 \mathrm{bB}$ & $536.04 \mathrm{bA}$ \\
\hline Hanging & $373.25 \mathrm{bB}$ & $89.31 \mathrm{aA}$ & $0.0116 \mathrm{bB}$ & $1.153 \mathrm{aA}$ & $504.99 \mathrm{bA}$ \\
\hline \multicolumn{6}{|l|}{$100-100$} \\
\hline Climbing & $430.10 \mathrm{bA}$ & $71.47 \mathrm{aB}$ & $0.0128 \mathrm{bA}$ & $0.990 \mathrm{bB}$ & $485.80 \mathrm{aA}$ \\
\hline Creeping & $481.00 \mathrm{aA}$ & $76.21 \mathrm{aB}$ & $0.0137 \mathrm{bA}$ & $1.232 \mathrm{aA}$ & $481.99 \mathrm{bA}$ \\
\hline Hanging & $442.16 \mathrm{aA}$ & $99.79 \mathrm{aA}$ & $0.0139 \mathrm{aA}$ & $1.308 \mathrm{aA}$ & $485.02 \mathrm{cA}$ \\
\hline
\end{tabular}

Different lowercase letters indicate significant differences for each growth parameter between AIA-BAP concentrations for the same training system while different capital letters indicate significant differences among training systems for each AIA-BAP concentration ( $<<0.05$ ).

(Figure 3A) with lower SLA (Table 1) and increased proportion of intercellular spaces, which may help decrease resistance to $\mathrm{CO}_{2}$ diffusion from the sub stomatal cavity to the chloroplast stroma (Figure 3B-D) (Tholen et al., 2012).

As reported before (Di Benedetto et al., 2015a, b), when E. aureum plants are grown in pots, roots are impeded to develop normally and this restriction may lead to a limited production of cytokinins by root apices. In turn, this affects shoot development because of the cytokinin promotive role on cell division in meristems (Skylar \& Wu, 2011). Then, exogenous cytokinin supply has been found to be an effective means of overcoming root restriction. The reason why exogenous IAA promoted growth in a similar manner than BAP may be less straight forward. A first possibility is a direct effect of auxin on both leaf expansion (Keller, 2007) and leaf initiation (Scarpella et al., 2010), because auxins move from the shoot meristems to the root apex. A more likely possibility, discussed by $\mathrm{Di}$ Benedetto et al. (2015b), is that auxin mediates cytokinin production due to its role on lateral root development, being root apices the sites of synthesis of cytokinin (Aloni et al., 2005).

In the present work, we also found that growth of hanging plants was effectively promoted in the same way than creeping ones. At high doses of both growth regulators in combined supply (e.g. 100-50 and 100-100 $\mathrm{mg} \mathrm{L}^{-1}$ IAA-BAP treatments), this promotion was enough to make RGR and NAR values of hanging plants similar to those of creeping ones.

On the other hand, growth regulators-sprayed climbing plants showed a general decrease in RLAE, mainly driven by a lower RLA (Table 3 ). They also showed lower RGR and NAR values than untreated controls in almost every growth regulators combination treatment (Table 1) while no clear trends in LAR were observed. These results, taken together, may be a response to a possible growth regulator (both auxin and cytokinin) deficiency in creeping and, especially, in hanging plants. Conversely, in hanging plants, endogenous auxin and cytokinin concentrations would not limit growth, and further increase in these concentrations through exogenous sprays could lead to supraoptimal levels with a negative impact on plant development.

Steinitz \& Hagiladi (1987) and Steinitz et al. (1992) described the promotive effect of thigmo-stimulation on foliage development in several Araceae including E. aureum. It is well known that plants respond to external (and internal) mechanical loads through mechano-sensing and transducing pathways that alter the expression of specific sets of transcription factors, ultimately responding by modifying growth rate and direction (Moulia et al., 
2016). In the case of E. aureum vines, soft stems grow in a hanging manner until they are mechano-stimulated by a surface on which they can climb. Nowadays, significant progress has been made in identifying stimulus-responsive elements and genes, as well as proteins, hormones and inorganic signalling molecules that are involved in plant response to mechanical and gravity stimuli (Coutand \& Mitchell, 2016). It is well known that thigmomorphogenetic responses are modulated by hormone homeostasis and especially by distribution patterns of auxins (Chehab et al., 2009). However, in our work, both thigmo- and gravimorphogenic effects may explain differences in plant development among training systems. Vine departure from upward growing position is expected to inhibit polar auxin transport from shoot apex to roots, which depends on stem position respect to the gravity vector (Lovisolo et al., 2002). Lower auxin levels in roots could in turn led to decreased root branching (Pacurar et al., 2014) and thus, lower cytokinin synthesis and export to shoots, being root apices the main site of synthesis of cytokinin synthesis (Pacifici et al., 2015). Exogenous growth regulators supply could then restore decreased endogenous hormonal levels in plants due to vine departure from vertical upward position.

Lopez et al. (2014) discuss models describing the gravitropic response following the tilting of plants, highlighted that gravitropic curvature involves both gravi-sensing and mechano-sensing, but noted that most experimental designs do not allow to discriminate between them. As was demonstrated through mathematical models of stem gravitropic movements (Bastien et al., 2013) that both gravisensing and mechano-sensing lead to the reorientation of the plant.

While Steinitz \& Hagiladi (1987) and Steinitz et al. (1992) attempted to separate touch and gravity stimulus by holding upper leaf petioles without touching sensitive stems, this procedure might have modified shoot apex position respect of climbing plants, which in turn could affect downward auxin movement and plant gravity perception. In our experiment, both climbing and creeping plants may be considered as thigmostimulated; therefore, differences in plant responses between them may be attributed to gravity effects, yet it must be taken into account that both stimuli appear not to act in an additive manner, but rather interact (Steinitz et al., 1992).

As Lopez et al. (2014) state, it remains a challenge to find an experimental design, which could allow discriminating between graviand mechano-sensing mechanisms. Furthermore, it is still not clear whether gravi-sensing and mechano-sensing act through the same mechanisms and to what extent one can differentiate these stimuli, since that gravi-sensing is derived from an ancestral touch perception apparatus.

Several conclusions can be drawn from the results of the present work. First, decreased leaf area development in hanging E. aureum plants, as compared to climbing ones, could be attributed to differences in both lower carbon assimilation (i.e., lower NAR and net photosynthetic rate) (Table 1 and Figure 2 respectively) and to a lower carbon assignment to leaf area development (larger root:shoot $\beta$ allometric coefficient, Table 2).

Second, creeping plants exhibited generally intermediate values, but regarding some variables (e.g., individual leaf area, Table 3); results

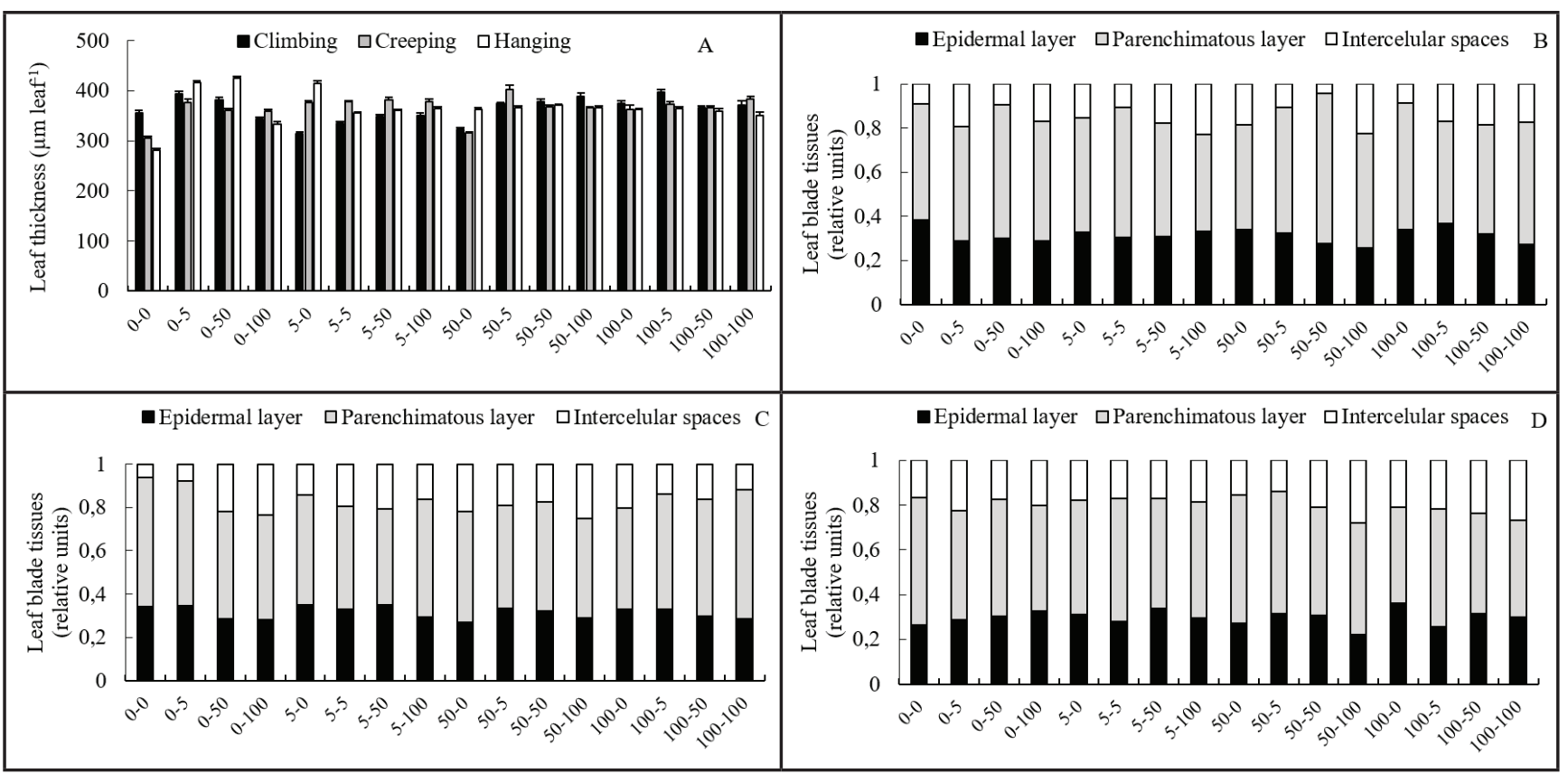

Figure 3. Changes in leaf thickness (A) and in leaf tissue distribution (\%) of E. aureum plants sprayed with four BAP concentrations ( 0 , 5, 50 and $100 \mathrm{mg} \mathrm{L}^{-1}$ ) but previously sprayed with IAA at $0,5,50$ or $100 \mathrm{mg} \mathrm{L}^{-1}$. Plants were grown under climbing (B), creeping (C) and hanging (D) training systems. Bar indicates least significant difference (LSD). Buenos Aires, UBA, 2008. 
were much closer to those of hanging plants than to those climbing, suggesting that any departure from upward growing position may severely affect $E$. aureum development.

Third, the effect of exogenous growth regulators applications widely differed among training systems: while in creeping and hanging plants growth was strongly enhanced by both IAA and BAP sprays, no promoting effect was observed in climbing ones. This is consistent with hormone deficiency in creeping and hanging plants, possibly due to impaired IAA transport to roots, and with possible supraoptimal hormone levels in sprayed climbing plants, although direct evidence to check these possibilities is needed.

Fourth, up to a good extent, growth promotion by exogenous growth regulators in creeping and hanging plants was attributable to the same factors that explained differences in growth parameters between training systems in the absence of exogenous growth regulators sprays (i.e. enhanced carbon assimilation per unit leaf area and enhanced accumulation of leaf area in plants treated with either IAA or BAP than in untreated controls) (Figure 2 and Table 3 respectively).

Fifth, the fact that both creeping (thigmo-stimulated) and hanging (non thigmo-stimulated) plants exhibited similarities in their behaviours, either in the absence or in the presence of exogenous growth regulators, in contrast with climbing (thigmo-stimulated) plants stresses the role of gravity on E. aureum responses to growth habit. While the regulation of plant form by mechanical stimuli has been described more than two centuries ago by Darwin, the subject has regained interest during the past four decades, partly because of its potential as an innovative means of controlling plant growth (Coutand \& Mitchell, 2016).

In the present work we show that not only E. aureum development is strongly affected by plant training system, but also that the response to exogenous AIA and BAP treatment varies drastically, either promoting or inhibiting growth, depending on vine orientation. This may in turn be of considerable applied value for the commercial grower, for who, 'pothos' price is mainly related to leaf and plant size.

\section{ACKNOWLEDGEMENTS}

This work formed part of a Ph.D. thesis by A.H. Di Benedetto at the Universidad Nacional de Cuyo, supported by the University of Buenos Aires Science Programme 2008-2011 (Grant $\mathrm{N}^{\circ} \mathrm{G054}$ ) and University of Mar del Plata 2008-2010 Science Programme (Grant N N AGR 259/08 and AGR 287/09).

The authors gratefully acknowledge to Dr Rodolfo Sánchez for its inspiring thoughts about this subject.

\section{REFERENCES}

ALONI, R; LANGHANS, M; ALONI, E; DREIEICHER, E; ULLRICH, CI. 2005. Root-synthesized cytokinin in Arabidopsis is distributed in the shoot by the transpiration stream. Journal of Experimental Botany 56: 1535-1544.

BASTIEN, R; BOHR, T; MOULIA, B; DOUADY, S. 2013. Unifying model of shoot gravitropism reveals proprioception as a central feature of posture control in plants. Proceedings of the National Academy of Science 110: 755-760.

CHEHAB, EW; EICH, E; BRAAM, J. 2009. Thigmomorphogenesis: a complex plant response to mechano-stimulation. Journal of Experimental Botany 60: 43-56.

COUTAND, C; MITCHELL, SJ. 2016 : Mechanical signalling in plants: from perception to consequences for growth and morphogenesis (thigmomorphogenesis) and ecological significance. Frontiers in Plant Science 7: 1441.

DE LOJO, J.; DI BENEDETTO, A. 2014. Biomass accumulation and leaf shape can be modulated by an exogenous spray of 6-benzylaminopurine in the ornamental foliage plant Monstera deliciosa (Liebm.). Journal of Horticultural Science \& Biotechnology 89: 136-140.

DI BENEDETTO, A; TOGNETTI, J.; GALMARINI, C. 2010. Biomass production in ornamental foliage plants: Crop productivity and mechanisms associated to exogenous cytokinin supply. The American Journal of Plant Science \& Biotechnology 4:1-22.

DI BENEDETTO, A; GALMARINI, C; TOGNETTI, J. 2013. Contribution of changes in leaf size and leaf production rate to cytokininmediated growth promotion in Epipremnum aureum L. Journal of Horticultural Science \& Biotechnology 88: 179-186.

DI BENEDETTO, A; GALMARINI, C; TOGNETTI, J. 2015a. Exogenous cytokinin promotes Epipremnum aureum L. growth through enhanced dry weight assimilation rather than through changes in partitioning. American Journal of Experimental Agriculture 5: 419-434.

DI BENEDETTO, A; GALMARINI, C; TOGNETTI, J. 2015b. Combined effect of exogenous auxin and cytokinin on Epipremnum aureum growth and leaf area development. Journal of Horticultural Science \& Biotechnology 90: 643-654.

KELLER, CP. 2007. Leaf expansion in Phaseolus: transient auxin-induced growth increase. Physiologia Plantarum 130: 580-589.

KELLER, M. 2015. The science of grapevines: Anatomy and physiology. Elsevier-Academic Press, $2^{\text {nd }}$ edition.

LI, ZG; GONG, M. 2011. Mechanical stimulationinduced cross-adaptation in plants: An overview. Journal of Plant Biology 54: 358-364.

LOPEZ, D; TOCQUARD, K; VENISSE, JS; LEGUÉ, V; ROECKEL-DREVET, P. 2014. Gravity sensing, a largely misunderstood trigger of plant orientated growth. Frontiers in Plant Science 5: 610.

LOVISOLO, C; SCHUBERT, A; SORCE, C. 2002. Are xylem radial development and hydraulic conductivity in downwardlygrowing grapevine shoots influenced by perturbed auxin metabolism? New Phytologist 156: 65-74.

MONSHAUSEN, GB; HASWELL, ES. 2013. A force of nature: molecular mechanisms of mechano perception in plants. Journal of Experimental Botany 64: 4663-4680.

MOULIA, B; COUTAND, C; JULIEN, JL. 2016. Mechanosensitive control of plant growth: bearing the load, sensing, transducing, and responding. Frontiers in Plant Science 6:52.

PACIFICI, E; POLVERARI, L; SABATINI, S. 2015. Plant hormone cross-talk: the pivot of root growth. Journal of Experimental Botany 66: 1113-1121.

PACURAR, DI; PERRONE, I; BELLINI, C. 2014. Auxin is a central player in the hormone cross-talks that control adventitious rooting. Physiologia Plantarum 151: 83-96.

SCARPELLA, E; BARKOULAS, M; TSIANTIS, M. 2010. Control of leaf and vein development by auxin. In: ESTELLE, M; WEIJERS, D; LJUNG, K; LEYSER, O (eds). Cold Spring Harbor Perspective Biology 2.

SKYKAR, A; WU, X. 2011. Regulation of meristem size by cytokinin signaling. Journal of Integrative Plant Biology 53: 446-454.

STEINITZ, B; HAG1LADI, A. 1987. Thigmomorphogenesis in climbing Epipremnum aureum, Monstera obliqua expilata and Philodendron scandens (Araceae). Journal of Plant Physiology 128: 461-466.

STEINITZ, B; HAGILADI, A; ANAV, D. 1992. Thigmomorphogenesis and its interaction with gravity in climbing plants of Epipremnum aureum. Journal of Plant Physiology 140: 571-574.

THOLEN, D; BOOM, C; ZHU, XG. 2012. Opinion: Prospects for improving photosynthesis by altering leaf anatomy. Plant Science 197: 92-101. 